\section{Phytotoxicity of Methiozolin on Fine Fescue}

\author{
Yuanshuo $\mathrm{Qu}^{1,3}$, Ryan M. Daddio ${ }^{1}$, Patrick E. McCullough ${ }^{2}$, \\ Stacy A. Bonos ${ }^{1}$, and William A. Meyer ${ }^{1}$
}

Additional index words. Dose-response analysis, Fesctuca sp., herbicide, Poa annua, turf management

Summary. Methiozolin is a new herbicide that controls annual bluegrass (Poa annua) in turfgrasses, but the differential tolerance levels of fine fescues (Festuca sp.) has received limited investigation. The objective of this study was to investigate the potential injury from methiozolin when applied to chewings fescue (Festuca rubra ssp. fallax), strong creeping red fescue (Festuca rubra ssp. rubra), and hard fescue (Festuca brevipila). Nine different fine fescue populations (14W2 Comp, Fairmont, and Survivor chewings fescue; FT345, Miser, and Fenway strong creeping red fescue; and 14H4 Comp, Stonehenge, and Oxford hard fescue) were sprayed with methiozolin at five different rates $(0.42,0.83,1.25,1.67$, and 2.09 $\mathrm{lb} /$ acre) at four different application timings [ 4 weeks before seeding (WBS), 2 WBS, at seeding (AS), and 2 weeks after germination (WAG)]. Untreated controls were also included for each combination. Significant reduction in germination of fine fescue was observed when methiozolin was applied before emergence for all tested application rates. Methiozolin at $1.25,1.67$, and $2.09 \mathrm{lb} /$ acre applied before or at the day of seeding led to complete inhibition of germination in all fine fescue species tested. It was less injurious compared with methiozolin applied at 2 WAG, although a reduction in the percentage of green cover and biomass was observed for application rates greater or equal to $0.83 \mathrm{lb} / \mathrm{acre}$. The hierarchical ranking of species injury from high to low is as follows: hard fescue, chewings fescue, and strong creeping red fescue. A possible solution for annual bluegrass control in fine fescue species with methiozolin is multiple postemergence applications up to a maximum rate of $0.83 \mathrm{lb} /$ acre. Turf managers need to make adjustments in methiozolin application rates and timings based on fine fescue species to maximize selectivity for annual bluegrass control.

$\mathrm{F}$ ine fescue is a group of several species in the genus Fesctuca, including chewings fescue, hard fescue, strong creeping red fescue, and slender creeping red fescue $(F$. rubra ssp. littoralis) (Bonos et al., 2006). They are known for drought and shade tolerance, as well as minimal requirements for maintenance and fertility. In recent years, the increasing demand for low-input turfgrass makes fine fescue species desirable for various turf uses (Watkins et al., 2012).

Received for publication 17 Jan. 2019. Accepted for publication 22 Feb. 2019.

Published online 1 May 2019

We thank Kyung-min Han from Moghu Research Center for providing the herbicide and the Rutgers Center for Turfgrass Science for technical support.

${ }^{1}$ Department of Plant Biology, Rutgers University, Foran Hall, 59 Dudley Road, New Brunswick, NJ 08901

${ }^{2}$ Crop and Soil Sciences Department, University of Georgia, Griffin, GA 30223

${ }^{3}$ Corresponding author. E-mail: yuanshuo.qu@rutgers. edu.

This is an open access article distributed under the CC BY-NC-ND license (https://creativecommons.org/ licenses/by-nc-nd/4.0/).

https://doi.org/10.21273/HORTTECH04278-19
The presence of annual bluegrass may reduce turf quality as a result of to its poor disease, heat, drought, and wear tolerances (Beard et al., 1978). Annual bluegrass is a prolific seed producer that germinates across a wide range of temperature, from 7 to $29{ }^{\circ} \mathrm{C}$ (McElroy et al., 2004). Annual bluegrass control in turfgrass requires integrated strategies of cultural and chemical control practices. Deep and infrequent irrigation encourages root development of desirable turfgrasses while reducing soil moisture for annual bluegrass infestations (Gaussoin and Branham, 1989). Turf managers may also collect clippings to minimize the return of annual bluegrass seeds to the soil, and balance fertility to enhance turfgrass competition with populations (Youngner, 1959). Preemergence herbicides are used to control annual bluegrass in turfgrass management, but applications often do not provide satisfying results because of poor efficacy of the available chemistries, herbicide resistance, or the presence of perennial biotypes (Callahan and McDonald, 1992; Isgrigg et al., 2002; Juska and Hanson, 1967; Yu and McCullough, 2014). Postemergence herbicides for annual bluegrass control in coolseason grasses, especially fine fescues, are limited. For example, amicarbazone and bispyribac-sodium can be used for annual bluegrass control in chewings fescue, creeping bentgrass (Agrostis stolonifera), perennial ryegrass (Lolium perenne), and tall fescue (Schedonorus arundinacea); however, there is concern over injury to other cultivated cool-season turfgrass species (Arysta LifeScience, 2012; Lycan and Hart, 2005; McCullough et al., 2010).

Methiozolin is a new herbicide in the isoxazoline chemical family. Koo et al. (2014) reported that it controlled annual bluegrass selectively in various cool- and warm-season turfgrasses. It has been evaluated extensively on creeping bentgrass, perennial ryegrass, and kentucky bluegrass (Poa pratensis) (Hoisington et al., 2014; McCullough and de Barreda, 2012). Methiozolin controls annual bluegrass postemergence when applied at 0.5 to $1 \mathrm{~kg} \cdot \mathrm{ha}^{-1}$ two to five times per year (Flessner et al., 2013; Koo et al., 2014; Xiong et al., 2015). Despite various research, little has been published to date on the phytotoxicity of methiozolin on fine fescue species. Therefore, this experiment was conducted to investigate the safety of methiozolin application regimens on hard fescue, chewings fescue, and strong creeping red fescue-the three most widely used fine fescue species. 


\section{Materials and methods}

Plant material. Nine fine fescue populations (three of each hard, chewings, and strong creeping red fine fescue) were chosen based on species, genetic diversity, and widespread use (Table 1). Square pots measuring $10 \times 10 \times 12 \mathrm{~cm}$ (length $\times$ width $\times$ depth), were filled with a $1: 2$ ratio $(\mathrm{v} / \mathrm{v})$ of commercial potting mix (Premier Pro-Mix 65-2005; Premier Tech Horticulture, Quakertown, PA) and sterilized sandy loam soil (collected from the Rutgers University Plant Science Research \& Extension Farm in Adelphia, NJ). Seeds of all fine fescue populations were handsown with a seeding rate of $20 \mathrm{~g} \cdot \mathrm{m}^{-2}$. Methiozolin (Moghu Research Center, Daejeon, Korea) was applied at five different rates- $0.42,0.83,1.25$, 1.67 , and $2.09 \mathrm{lb} /$ acre-at four different application timings: 4 WBS, $2 \mathrm{WBS}$, AS, and 2 WAG. Untreated controls were also included for each population. Methiozolin and fertilizer applications were applied using a carbon dioxide pressurized track sprayer (no. SB8-211; DeVries Manufacturing, Hollandale, $\mathrm{MN}$ ) equipped with a flat fan nozzle (8002EVS; TeeJet Technologies, Springfield, PA), calibrated to deliver $150 \mathrm{gal} / \mathrm{acre}$. All plants were fertilized 4 weeks after germination with a water-soluble, general-purpose $20 \mathrm{~N}-8.8 \mathrm{P}-17.6 \mathrm{~K}$ fertilizer (Peter's Professional; Scotts, Marysville, $\mathrm{OH}$ ) at the nitrogen rate of $2.4 \mathrm{~g} \cdot \mathrm{m}^{-2}$.

EXPERIMENTAL DESIGN AND DATA COLLECTION. The experiments were arranged in a randomized complete block design with three replications and were conducted in a greenhouse at Rutgers University in New Brunswick, NJ. Average daily temperature was maintained at $24 \pm$ $10{ }^{\circ} \mathrm{C}$, with relative humidity at $35 \%$. The first experiment was carried out from 1 Dec. 2014 to 2 Mar. 2015 and was repeated from 8 Mar. to 9 June 2015. Digital images of plants were captured using a digital camera (ST70; Samsung, Seoul, South Korea) mounted to a portable lightbox equipped with four fullspectrum compact fluorescent lamp light bulbs (1855-55-04-JL; ALZO Digital, Bethel, CT) at 2, 4, 6, and 8 WAG. Digital image analysis was conducted to determine percentage green cover using SigmaScan Pro (version 5.0; Systat Software, San Jose, CA) as described by Richardson et al. (2001). The color spectrum in SigmaScan was set with hue values within the range of 40 to 140 and saturation values within the range of 10 to 100 . Before termination of the experiments, aboveground plant tissue of tested fine fescue from each pot was harvested at $8 \mathrm{WAG}$, with dry weight recorded after $3 \mathrm{~d}$ at $50{ }^{\circ} \mathrm{C}$. Green cover and shoot biomass data were expressed as a percentage of the untreated control for each experiment. Lacking a significant experiment-bytreatment interaction, all data were combined over experiments for further analysis.

Data Analysis. Dry weight data collected at 8 WAG were subject to analysis of variance (ANOVA) in R version 3.3.2, with dry weight at 8 WAG as the dependent variable; and methiozolin rate, application timing, species, and rate $\times$ timing interactions as independent variables.

Dry weight data collected at 8 WAG were fitted to a log-logistic model described by Seefeldt et al. (1995), given by the formula

$$
\begin{aligned}
f(x \mid b, c, d, e)= & c+(d-c) /\{1+\exp [b(\log (x) \\
& -\log (e))]\},
\end{aligned}
$$

where dry weight, $f(x)$, is a conditional function of the application rate $x$. ED50, which is denoted by $e$, is the effective dose to reduce dry weight by $50 \%$. Parameters $d$ and $c$ define the range of response variables. During the data analysis portion of this project, $d$ and $c$ were set at one and zero, respectively, as data were converted to percentage of untreated control (8 WAG). Parameter $b$ denotes the relative slope around $e$. Green cover data were fitted to the same model to estimate the $\mathrm{I}_{20}$ value, which is the effective dose to reduce green cover by $20 \%$. Estimation and inference of model parameters were realized using R package "drc" (Ritz et al., 2015). $\mathrm{ED}_{50}$ is a commonly used measure for the reasonable expectancy of a chemical effect whereas $\mathrm{I}_{20}$ indicates the benchmarks for acceptable injury to intensively managed turfgrasses (McCullough et al., 2016). Comparison of $\mathrm{ED}_{50}$ and $\mathrm{I}_{20}$ values was carried out by pairwise $t$ test with the Bonferroni method for correction

Table 1. Fine fescue populations treated with methiozolin herbicide to evaluate

\begin{tabular}{|c|c|c|}
\hline Species & Population $^{\mathrm{z}}$ & Source \\
\hline \multirow[t]{3}{*}{ Chewings fescue } & 14W2 Comp & $\begin{array}{l}\text { Rutgers University, Plant Science Research and } \\
\text { Extension Farm, Adelphia, NJ }\end{array}$ \\
\hline & Fairmont & Landmark Turf \& Native Seed, Spokane, WA \\
\hline & Survivor & Pennington Seed, Lebanon, OR \\
\hline \multirow[t]{3}{*}{ Hard fescue } & 14H4 Comp & $\begin{array}{l}\text { Rutgers University, Plant Science Research and } \\
\text { Extension Farm }\end{array}$ \\
\hline & Stonehenge & Blue Mountain Seeds, Imbler, OR \\
\hline & Oxford & Lebanon Seaboard Corp., Lebanon, PA \\
\hline \multirow[t]{3}{*}{$\begin{array}{l}\text { Strong creeping } \\
\text { red fescue }\end{array}$} & FT345 & $\begin{array}{l}\text { Rutgers University, Plant Science Research and } \\
\text { Extension Farm }\end{array}$ \\
\hline & Miser & ProSeeds Marketing Inc., Jefferson, OR \\
\hline & Fenway & Blue Mountain Seeds \\
\hline
\end{tabular}
phytotoxicity.

${ }^{\mathrm{z}}$ Cultivar or synthetic population.

Table 2. Analysis of variance table showing variance components for the effects of different application rate $(\mathrm{R})$ - the application timing $(T)$ of methiozolin herbicide on shoot biomass of different fine fescue species measured at 8 weeks after germination.

\begin{tabular}{lrccrl}
\hline Source of variation & df & Sum of square & Mean square & F value & Pvalue \\
\hline $\mathrm{R}$ & 4 & 30.79 & 7.70 & 121.87 & $<0.001$ \\
$\mathrm{~T}$ & 3 & 132.81 & 44.27 & 700.88 & $<0.001$ \\
Species & 2 & 1.17 & 0.59 & 9.29 & $<0.001$ \\
$\mathrm{R} \times \mathrm{T}$ & 12 & 2.89 & 0.24 & 3.81 & $<0.001$ \\
Residuals & 1058 & 66.83 & 0.06 & & \\
\hline
\end{tabular}


Table 3. Estimates of parameters from regression analysis performed on fine fescue shoot biomass data measured at 8 weeks after germination.

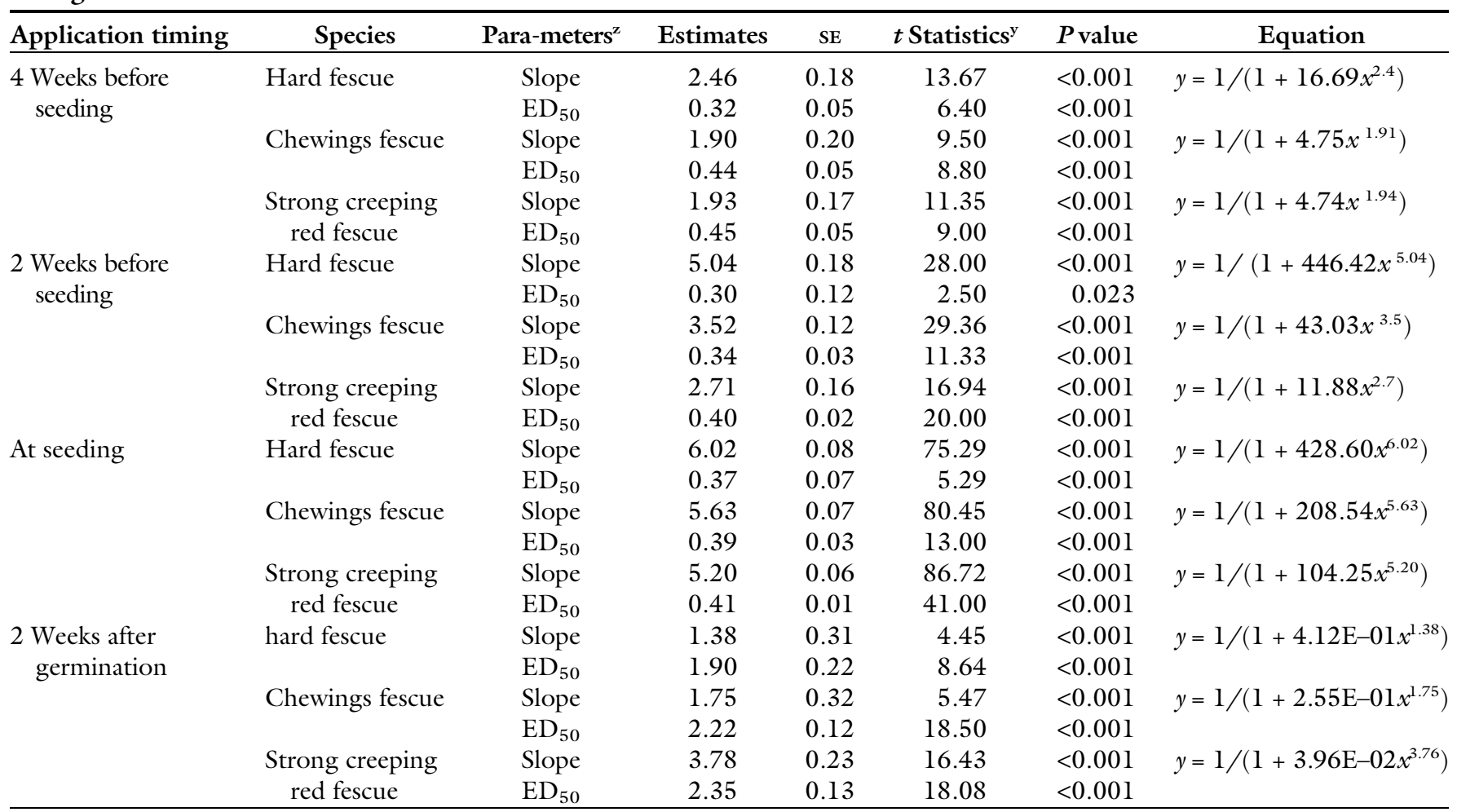

${ }^{\mathrm{z}} \mathrm{ED}_{50}=$ dose of methiozolin to reduce biomass (percentage untreated) by $50 \%$.

${ }^{y}$ The $t$ statistics and corresponding probabilities are for testing the null hypothesis that the parameters are equal to zero.

of multiple comparisons (Hothorn et al., 2008; Ritz et al., 2015). All figures were generated using $\mathrm{R}$ package "ggplot2" (Wickham, 2011).

\section{Results and discussion}

SHOOT BIOMASS ANALYSIS. ANOVA showed all three covariates (methiozolin rate, application timing, and species) affected dry weight significantly at 8 WAG. Methiozolin rate $\times$ application timing interactions were also significant $(P<0.001)$ for shoot biomass reductions from the untreated control, suggesting changes in the application rate would influence shoot biomass at $8 \mathrm{WAG}$, but differently depending on the application timing of methiozolin (Table 2). No significant differences $(P=0.804)$ were observed across populations within each species in $\mathrm{ED}_{50}$ values; hence, cultivars within a species were combined and the dose-response analysis was conducted on different species and $\mathrm{ED}_{50}$ values were estimated separately.

When methiozolin was applied 4 WBS, a greater reduction in shoot biomass was detected in hard fescue for all application rates compared

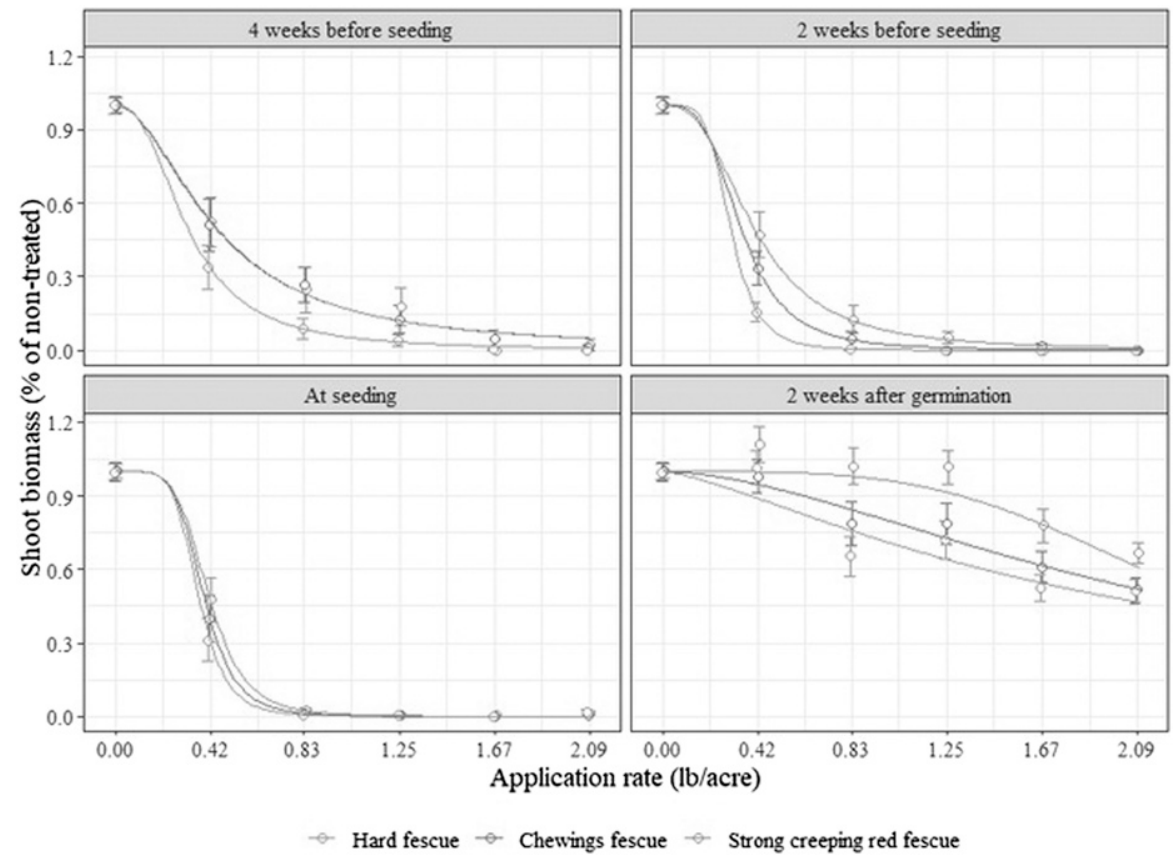

Fig. 1. Dose-response curves estimated based on shoot biomass at 8 weeks after germination with methiozolin applied at four different timings. The fitted curves for hard fescue, chewings fescue, and strong creeping red fescue, started from the earliest application timing to the latest one are $y=1 /\left(1+16.69 x^{2.4}\right), y=1 /(1+$ $\left.4.75 x^{1.91}\right), y=1 /\left(1+4.74 x^{1.94}\right), y=1 /\left(1+446.42 x^{5.04}\right), y=1 /\left(1+43.03 x^{3.5}\right)$, $y=1 /\left(1+11.88 x^{2.7}\right), y=1 /\left(1+428.60 x^{6.02}\right), y=1 /\left(1+208.54 x^{5.63}\right), y=1 /$ $\left(1+104.25 x^{5.20}\right), y=1 /\left(1+4.12 \mathrm{E}-01 x^{1.38}\right), \mathrm{y}=1 /\left(1+2.55 \mathrm{E}-01 x^{1.75}\right), y=1 /$ $\left(1+3.96 \mathrm{E}-02 x^{3.76}\right)$, respectively. The vertical bars represent the SE of estimates from eight independent measurements. $1 \mathrm{lb} / \mathrm{acre}=1.1209 \mathrm{~kg} \cdot \mathrm{ha}^{-1}$. 
with chewings and strong creeping red fescue. Estimated $\mathrm{ED}_{50}$ values for methiozolin applied at 4 WBS were in accord with this observation, $\mathrm{ED}_{50}$ of hard fescue was $0.32 \pm 0.05 \mathrm{lb} /$ acre (mean $\pm \mathrm{SE}$ ), whereas that of chewings fescue and strong creeping red fescue was $0.45 \pm 0.04 \mathrm{lb} /$ acre with significant differences (Table 3 ). It is not surprising that chewings fescue and strong creeping red fescue performed similarly because they both belong to red fescue [ $F$. rubra (Ruemmele et al., 1995)]. When methiozolin was applied at 2 WBS, the hierarchical rank of species injury from high to low was hard fescue > chewings fescue > strong creeping red fescue. When the application rate exceeded 1.25 $\mathrm{lb} / \mathrm{acre}$, shoot biomass production was minimal for all three species.

There were no significant differences in $\mathrm{ED}_{50}$ among species when methiozolin was applied 2 WBS or AS. Methiozolin inhibited germination of all fine fescue species when applied at seeding with a rate greater than $0.83 \mathrm{lb} /$ acre. The $\mathrm{ED}_{50}$ values for fine fescue measured $0.32 \pm 0.02$ and $0.39 \pm 0.01 \mathrm{lb} /$ acre, respectively. When methiozolin was applied 2 WAG, shoot biomass declined as the application rate increased. Predicted $\mathrm{ED}_{50}$ values are $1.90 \pm 0.22,2.19 \pm$ 0.12 , and $2.35 \pm 0.13 \mathrm{lb} /$ acre for hard fescue, chewings fescue, and strong creeping red fescue, respectively. Pairwise $t$ tests with Bonferroni correction showed significant differences in $\mathrm{ED}_{50}$ among the three species at 2 WAG. Similarly, hard fescue exhibited the least tolerance to methiozolin followed by chewings fescue, and strong creeping red fescue had the highest tolerance, as shown in Fig. 1 and Table 3.

Briefly, when applied 4 WBS, 2 WBS, or AS, methiozolin reduced germination of all tested fine fescue populations to unacceptable levels at all tested rates, including the lowest rate of $0.42 \mathrm{lb} /$ acre. Greater application rates and a shorter interval between application timing and seeding led to lower biomass production. Specifically, when applied at seeding, with an application rate greater than $0.83 \mathrm{lb} /$ acre, methiozolin inhibited germination of all three species completely. Flessner et al. (2013) reported limited mobility of methiozolin in a sand-based root zone, suggesting resistance to loss through leaching displacement, which might explain the residual effects of methiozolin. Brosnan et al. (2017) conducted a dose-response analysis of methiozolin on several annual bluegrass phenotypes and concluded that rates required to reduce aboveground biomass by $50 \%$ range from 0.159 to $0.862 \mathrm{~kg} \cdot \mathrm{ha}^{-1}$. Our findings indicate that delaying applications until 2 WAG may result in acceptable tolerance of fine fescues while effectively control annual bluegrass.

GreEN COVER ANALYSIS. I $\mathrm{I}_{20}$ values showed no significant differences $(P=0.716)$ among species when methiozolin was applied 4 WBS, 2 WBS, and AS. The corresponding $\mathrm{I}_{20}$ for different species pooled together was estimated at $0.18 \pm 0.02,0.22 \pm 0.03$, and $0.30 \pm$ $0.03 \mathrm{lb} /$ acre. In general, reduction in green percentage cover was observed across all fine fescue populations, as shown in Fig. 2 and Table 4. It has been reported that methiozolin controls annual bluegrass postemergence when applied at 0.5 to $\mathrm{l} \mathrm{kg} \cdot \mathrm{ha}^{-1}$ two to five times per year (Flessner et al., 2013; Koo et al., 2014; Xiong et al., 2015). Our data suggest that for preemergence control of annual bluegrass, such a rate could lead to a reduction of more than $20 \%$ in green cover. When methiozolin was applied $2 \mathrm{WAG}$, predicted $\mathrm{I}_{20}$ values for hard fescue, chewings fescue, and strong creeping red fescue were $0.67 \pm 0.11,1.13 \pm 0.13$, and $1.25 \pm$ $0.19 \mathrm{lb} /$ acre, respectively. Pairwise $t$ tests with Bonferroni correction showed significant differences between $\mathrm{I}_{20}$ of hard fescue and those of the other two species. Similarly, hard fescue was the most susceptible to methiozolin, followed by chewings fescue and strong creeping red fescue, which showed the least injury.

All untreated fine fescue species had increased green cover from about $15 \%$ to $90 \%$ from 2 to 8 WAG; no significant difference in seedling vigor was observed. Reduction in green cover was primarily the result of inhibition of germination when methiozolin was applied before and at seeding. When it was applied 4 WBS, $2 \mathrm{WBS}$, and AS with rates greater than

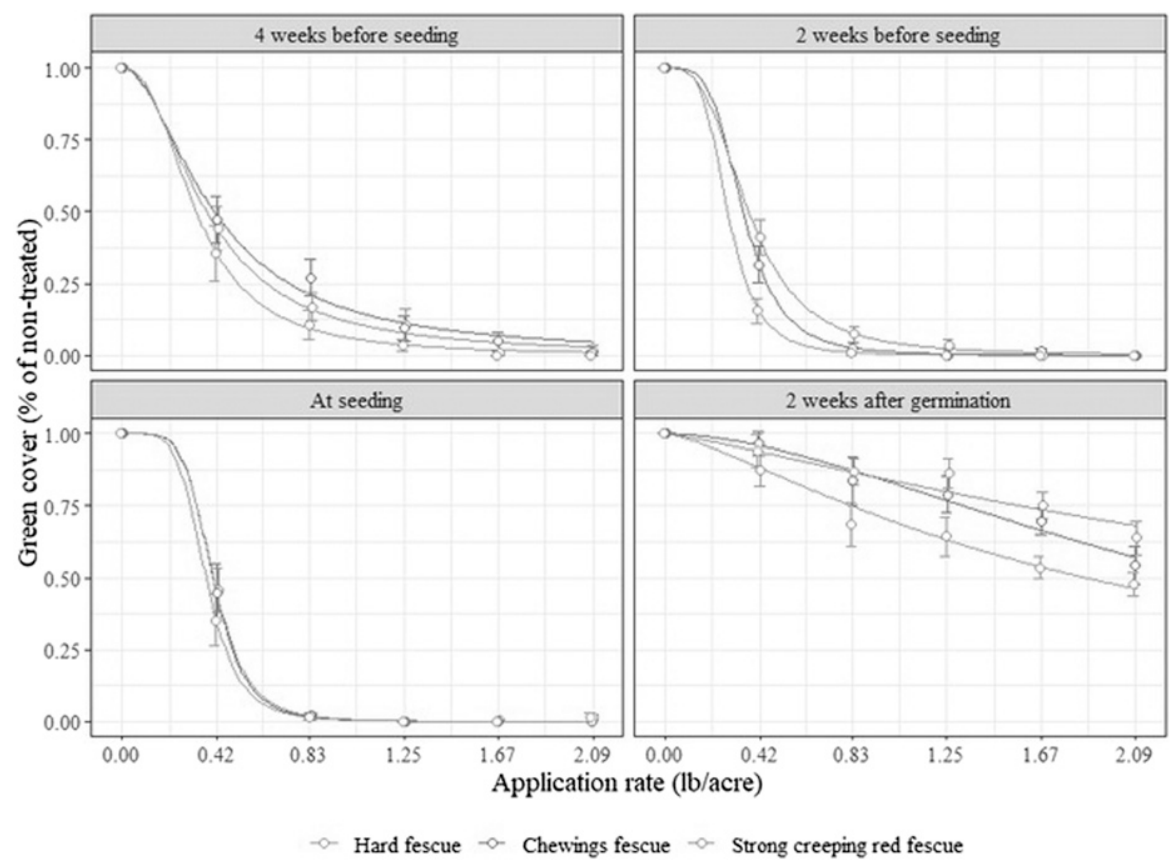

Fig. 2. Dose-response curves estimated based on green cover at 8 weeks after germination with methiozolin applied at four different timings. The fitted curves for hard fescue, chewings fescue, and strong creeping red fescue, started from the earliest application timing to the latest one are $y=1 /\left(1+15.23 x^{2.44}\right), y=1 /(1+$ $\left.5.23 x^{1.85}\right), y=1 /\left(1+7.50 x^{2.05}\right), y=1 /\left(1+215.27 x^{4.19}\right), y=1 /\left(1+79.96 x^{4.13}\right)$, $y=1 /\left(1+20.98 x^{3.07}\right), y=1 /\left(1+179.91 x^{5.24}\right), y=1 /\left(1+171.11 x^{5.64}\right), y=1 /$ $\left(1+136.21 x^{5.43}\right), y=1 /\left(1+0.43 x^{1.35}\right), y=1 /\left(1+0.20 x^{1.79}\right), y=1 /(1+$ $\left.0.19 x^{1.21}\right)$, respectively. The vertical bars represent SE of estimates from eight independent measurements; $1 \mathrm{fl} \mathrm{oz} /$ acre $=0.0731 \mathrm{~L} \cdot \mathrm{ha}^{-1}$. 


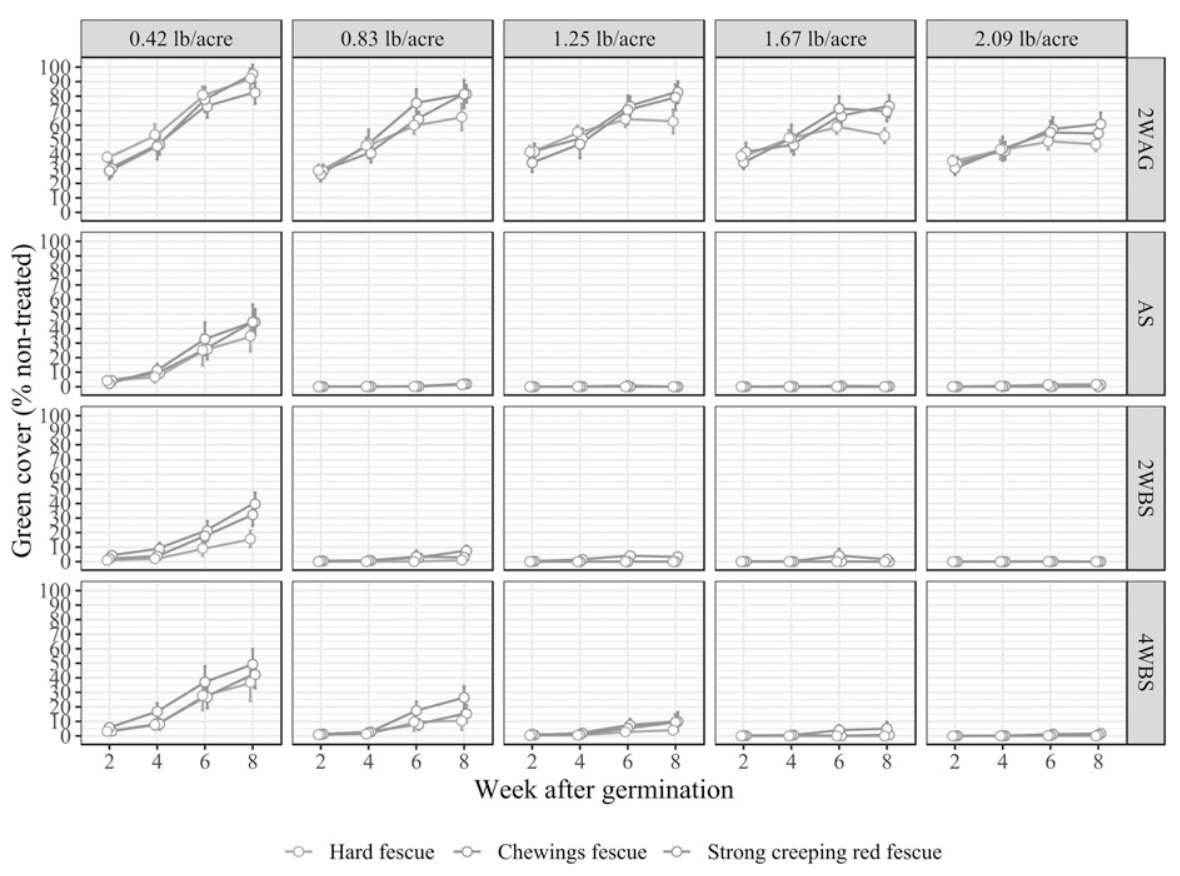

Fig. 3. Green cover measured at 8 weeks after germination of different fine fescue species after germination with methiozolin applied at different timing and rate combinations. Application timings are labeled on the right and are 4 weeks before seeding (WBS), 2 WBS, at seeding (AS), and 2 weeks after germination (WAG). Application rates are labeled on top and are $0.42,0.83,1.25,1.67$, and $2.09 \mathrm{lb} /$ acre; $1 \mathrm{lb} /$ acre $=1.1209 \mathrm{~kg} \cdot \mathrm{ha}^{-1}$.
$0.83 \mathrm{lb} / \mathrm{acre}$, green cover of all three fine fescue species measured less than $30 \%$ of the untreated control (Fig. 3). Significant reduction in green cover was also observed when methiozolin was applied before seeding with a rate of $0.42 \mathrm{lb} /$ acre. In all three application regimes (4 WBS, 2 WBS, and AS), green percentage cover only achieved up to $45 \%$ of the untreated control when measured at 8 WAG. Methiozolin was less injurious to fine fescues when applied at 2 WAG. No significant reduction in green cover was observed when methiozolin was applied $2 \mathrm{WAG}$ at $0.42 \mathrm{lb} /$ acre for the fine fescues. A decline in green cover was observed at greater application rates in all three fine fescue species. Hard fescue exhibited faster reduction in green percentage cover compared with the other two species. The results from green cover analysis concurred with previous doseresponse analyses (Figs. 1 and 2, Tables 3 and 4). McCullough and de Barreda (2012) reported methiozolin at $0.56,1.12$, and $2.24 \mathrm{~kg} \cdot \mathrm{ha}^{-1}$ applied AS reduced groundcover of

Table 4. Estimates of parameters from regression analysis performed on green cover data measured at 8 weeks after germination.

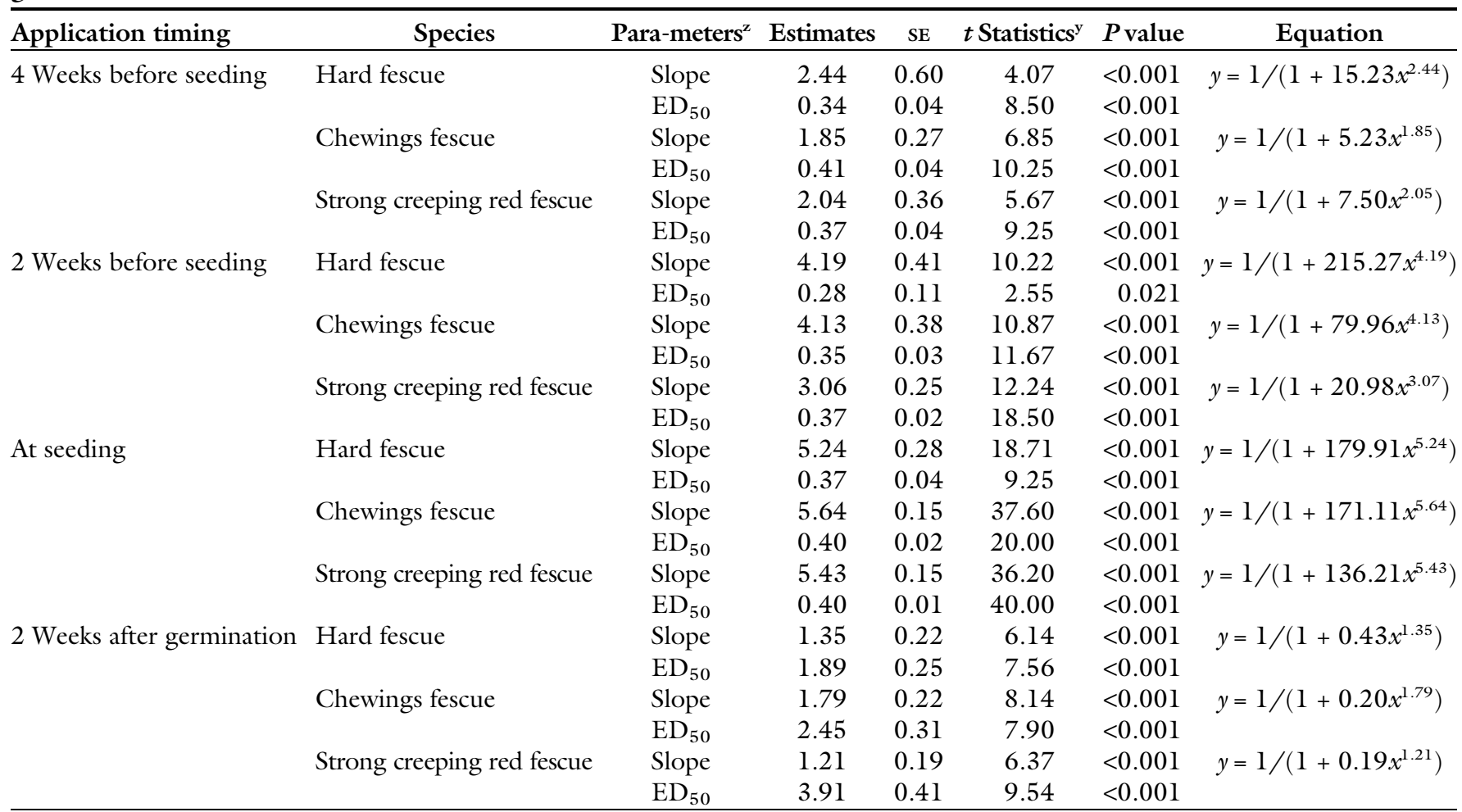

${ }^{\mathrm{z}} \mathrm{ED}_{50}=$ dose of methiozolin to reduce green cover (percentage untreated) by $50 \%$ at 8 weeks after germination

${ }^{\mathrm{y}}$ The $t$ statistics and corresponding probabilities are for testing the null hypothesis that the parameters are equal to zero. 
perennial ryegrass and tall fescue. Fine fescues seem to be more sensitive to methiozolin compared with perennial ryegrass and tall fescue based on this experiment. Hoisington et al. (2014) evaluated the relative tolerance of three bentgrass species to methiozolin in greenhouse studies and found that creeping bentgrass was more tolerant than velvet bentgrass (Agrostis canina) and colonial bentgrass (Agrostis caplillaris). Similar species variation in response to methiozolin was seem in our experiment.

In summary, hard fescue showed the greatest sensitivity to methiozolin in all application regimes. Green percentage cover of hard fescue decreased quickly as the application rate increased. Reduction in green percentage cover was primarily the result of increasing senescence and discolored leaves when methiozolin was applied at $2 \mathrm{WAG}$. Fine fescues seem to have greater susceptibility to methiozolin than tall fescue and perennial ryegrass, and further research is needed to evaluate application rates and regimens that maximize selectivity for weed control. More important, genetic differences among fine fescue species may contribute to differential tolerance levels to methiozolin. Hard fescue managers should be cautious and may need to reduce application rates of methiozolin because these cultivars have greater susceptibility to injury than chewings fescue and strong creeping red fescue.

\section{Literature cited}

Arysta LifeScience. 2012. Xonerate herbicide label. Arysta LifeScience, Cary, NC.

Beard, J.B., P.E. Rieke, A.J. Turgeon, and J.M. Vargas. Jr. 1978. Annual bluegrass (Poa annua L.): Description, adaptation, culture and control. Michigan State Univ., Agr. Expt. Sta. Res. Rpt. 352.

Bonos, S.A., B.B. Clarke, and W.A. Meyer. 2006. Breeding for disease resistance in the major cool-season turfgrasses. Annu. Rev. Phytopathol. 44:213-234.
Brosnan, J.T., J.J. Vargas, G.K. Breeden, S.L. Boggess, M.A. Staton, P.A. Wadl, and R.N. Trigiano. 2017. Controlling herbicide-resistant annual bluegrass (Poa annua) phenotypes with methiozolin. Weed Technol. 31(3):470-476.

Callahan, L.M. and E.R. McDonald. 1992. Effectiveness of bensulide in controlling two annual bluegrass (Poa annua) subspecies. Weed Technol. 6(1):97-103.

Flessner, M.L., G.R. Wehtje, and J.S. McElroy. 2013. Methiozolin absorption and translocation in annual bluegrass ( $P o a$ annua). Weed Sci. 61(2):201-208.

Gaussoin, R.E. and B.E. Branham. 1989. Influence of cultural factors on species dominance in a mixed stand of annual bluegrass/creeping bentgrass. Crop Sci. 29(2):480-484.

Hoisington, N.R., M.L. Flessner, M. Schiavon, J.S. McElroy, and J.H. Baird. 2014. Tolerance of bentgrass (Agrostis) species and cultivars to methiozolin. Weed Technol. 28(3):501-510.

Hothorn, T., F. Bretz, and P. Westfall. 2008. Simultaneous inference in general parametric models. Biometrical J. 50(3): 346-363.

Isgrigg, III, J., F.H. Yelverton, C. Brownie, and L.S. Warren. 2002. Dinitroaniline resistant annual bluegrass in North Carolina. Weed Sci. 50(1):86-91.

Juska, F.V. and A.A. Hanson. 1967. Factors affecting Poa annua L. control. Weeds 15(2):98-101.

Koo, S.J., K.H. Hwang, M.S. Jeon, S.H. Kim, J. Lim, D.G. Lee, and N.G. Cho. 2014. Methiozolin [5-(2, 6-difluorobenzyl) oxymethyl-5-methyl-3, 3 (3-methylthiophen-2-yl)-1, 2-isoxazoline ], a new annual bluegrass (Poa annua L.) herbicide for turfgrasses. Pest Mgt. Sci. 70(1):156-162.

Lycan, D.W. and S.E. Hart. 2005. Coolseason turfgrass response to bispyribacsodium. HortScience 40:1552-1555.

McCullough, P.E. and D.G. de Barreda. 2012. Cool-season turfgrass reseeding intervals for methiozolin. Weed Technol. 26(4):789-792.
McCullough, P.E., S.E. Hart, D. Weisenberger, and Z.J. Reicher. 2010. Amicarbazone efficacy on annual bluegrass and safety on cool-season turfgrasses. Weed Technol. 24:461-470.

McCullough, P.E., J. Yu, M.A. Czarnota, and P.L. Raymer. 2016. Physiological basis for metamifop selectivity on bermudagrass (Cynodon dactylon) and goosegrass (Eleusine indica) in cool-season turfgrasses. Weed Sci. 64(1):12-24.

McElroy, J.S., R.H. Walker, G.R. Wehtje, and E. van Santen. 2004. Annual bluegrass (Poa annua) populations exhibit variation in germination response to temperature, photoperiod, and fenarimol. Weed Sci. 52(1):47-52.

Richardson, M.D., D.E. Karcher, and L.C. Purcell. 2001. Quantifying turfgrass cover using digital image analysis. Crop Sci. 41(6):1884-1888

Ritz, C., F. Baty, J.C. Streibig, and D. Gerhard. 2015. Dose-response analysis using R. PLoS One 10(12):e146021.

Ruemmele, B.A., L.A. Brilman, and D.R. Huff. 1995. Fine fescue germplasm diversity and vulnerability. Crop Sci. 35(2):313-316.

Seefeldt, S.S., J.E. Jensen, and E.P. Fuerst. 1995. Log-logistic analysis of herbicide dose-response relationships. Weed Technol. 9(2):218-227.

Watkins, E., C. Yue, and K. Hugie. 2012. Are consumers willing to pay more for low-input turfgrasses on residential lawns? Evidence from choice experiments. J. Agr. Appl. Econ. 44(4):549-560.

Wickham, H. 2011. ggplot2. Wiley Interdiscip. Rev. Comput. Stat. 3(2): 180-185.

Xiong, X., J.Q. Moss, J.B. Haguewood, and K. Koh. 2015. Safety of sequential fall methiozolin applications on creeping bentgrass putting greens. Crop Forage Turfgrass Mgt. 1(1):1-8.

Youngner, V.B. 1959. Ecological studies on Poa annua in turfgrasses. Grass Forage Sci. 14(4):233-237.

$\mathrm{Yu}$, J. and P.E. McCullough. 2014. Methiozolin efficacy, absorption, and fate in six cool-season grasses. Crop Sci. 54(3): 1211-1219. 